\title{
A Case Report on Allergic Reaction to Pantoprazole
}

\author{
Rashi Bahuguna $^{1}$, Devesh Joshi ${ }^{1}$, Madhulata Rana ${ }^{2}$ \\ ${ }^{1}$ Pharm.D. Student, Department of Pharmacy Practice, \\ Shri Guru Ram Rai Institute of Technology \& Science, Dehradun, Uttarakhand, India \\ ${ }^{2}$ Professor, Department of Surgery,
}

Shri Guru Ram Rai Institute of Medical and Health Sciences, Dehradun, Uttarakhand, India

Corresponding Author: Rashi Bahuguna

\begin{abstract}
Pantoprazole is a proton pump inhibitor and acts by blocking the gastric pump $\mathrm{H}+, \mathrm{K}-\mathrm{ATPase}$ to inhibit gastric acid secretion. Hypersensitivity reactions due to pantoprazole can be both immediate and delayed hypersensitivity reactions but sometimes it can be a lifethreatening anaphylactic reaction. A 64-year female was admitted to the private ward of Shri Mahant Indiresh hospital with chief complaints of 6-7 episodes of vomiting and abdominal pain. Various laboratory tests were performed and the diagnosis was given. After the administration of Injection pantoprazole $40 \mathrm{mg}$ patient developed rashes, itching, vomiting, burning sensation in whole body, restlessness, fever, and chills immediately within few hours. Hypersensitivity reaction to pantoprazole occurred due to Type-1 hypersensitivity reaction. Proton pump inhibitors like pantoprazole decrease gastric $\mathrm{pH}$ which increases bacterial growth in the oral cavity and upper GIT. To check on such ADR's health care professionals should keep an eye on the medication use and its effects and should be cautious while prescribing pantoprazole. Pharmacists should educate the patients regarding possible hypersensitivity reactions from PPIs and how to take these medications to avoid any serious adverse drug reaction.
\end{abstract}

Keywords: PTCA-Percutaneous transluminal coronary angioplasty, CBC-Complete Blood Count, RFT-Renal Function tests, LFT-Liver function tests, Hb-Hemoglobin, TLC-Total Leucocyte count, PCV-Packed cell volume, RBC-Red Blood Cells, RDW-Red cell distribution width, SGOT-Serum Glutamic oxaloacetic transaminases, ALP-Alkaline phosphatase, GGT-Gamma Glutamyl transferase, PR-Pulse rate, RR-Respiratory rate, BP-Blood Pressure, Temp-Temperature, SpO2Oxygen saturation.

\section{INTRODUCTION}

Pantoprazole is a proton pump inhibitor and acts by blocking the gastric pump $\mathrm{H}+$, K-ATPase to inhibit gastric acid secretion ${ }^{1}$. Proton pump inhibitors are used for the treatment of diseases like altered intestinal $\mathrm{pH}$, Barrett's esophagus, peptic ulcer, gastroesophageal reflux disease

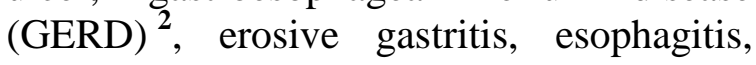
duodenal ulcer, and Zollinger Ellison syndrome ${ }^{3}$. Proton pump inhibitors get metabolized in the liver so they are not directly hepatotoxic ${ }^{4}$ but hypersensitivity reactions can occur due to proton pump inhibitors ${ }^{5}$.

Hypersensitivity reactions due to pantoprazole can be both immediate and delayed hypersensitivity reactions but sometimes it can be life threatening anaphylactic reaction ${ }^{6,7}$.

Immediate Hypersensitivity reaction: The reaction to the drug that occurs within 24 hours of drug administration is called immediate hypersensitivity ${ }^{\mathbf{8 , 9 , 1 0}}$.

Delayed Hypersensitivity reaction: The reaction that occurs between 24 to 48 hours of interval after drug administration is called delayed hypersensitivity reaction ${ }^{\mathbf{8 , 9 , 1 0}}$. 
Proton pump inhibitors are usually well-tolerated and do not have any severe adverse drug reactions. The Uppsala monitoring center database has $0.2 \%-0.7 \%$ of all incidences of anaphylaxis of both $\mathrm{H} 2$ receptor antagonists and PPIs ${ }^{\mathbf{1 1}}$.

The causative drug and a causality relationship between the drug and the reaction are essential to optimize therapeutic safety and identification of hypersensitivity reactions ${ }^{\mathbf{1 2}}$.

\section{CASE REPORT}

A 64-year old female was admitted to the private ward of Shri Mahant Indiresh hospital with chief complaints of 6-7 episodes of vomiting and abdominal pain. The patient was a non-vegetarian and was an ex-chulha worker and had a history of 12 cycles of lung chemotherapy with post percutaneous transluminal coronary angioplasty (PTCA) in 2016. Various laboratory tests were prescribed to the patient for diagnosis.

\begin{tabular}{|c|l|c|c|}
\hline S.No. & \multicolumn{1}{|c|}{ Laboratory Test } & Observed Value & Normal Value \\
\hline A. & Complete Blood Count & & \\
\hline i. & Hb & $9.90 \mathrm{~g} / \mathrm{dl}(\mathrm{L})$ & $11.5-15 \mathrm{~g} / \mathrm{dl}$ \\
\hline ii. & PCV & $29.5 \%(\mathrm{~L})$ & $36-46 \%$ \\
\hline iii. & RBC & $3.44 \mathrm{million} / \mathrm{mm}^{3}(\mathrm{~L})$ & $3.8-4.8 \mathrm{million} / \mathrm{mm}^{3}$ \\
\hline iv. & RDW & 15.70 & $11.5-14.5$ \\
\hline v. & TLC & $2.9 \mathrm{cell} / \mathrm{mm}^{3}$ & $5-10 \mathrm{cell} / \mathrm{mm}^{3}$ \\
\hline vi. & Monocytes & $12.40 \%$ & $2-10 \%$ \\
\hline vii. & Eosinophils & $0.70 \%$ & $1-6 \%$ \\
\hline viii. & Lymphocytes & $0.87 / \mathrm{mm}^{3}$ & $0.87 / \mathrm{mm}^{3}$ \\
\hline B. & Liver Function Tests & & $14-36 \mathrm{U} / \mathrm{L}$ \\
\hline i. & SGOT & $87 \mathrm{U} / \mathrm{L}(\mathrm{H})$ & $38-126 \mathrm{U} / \mathrm{L}$ \\
\hline ii. & ALP & $183 \mathrm{U} / \mathrm{L}(\mathrm{H})$ & $12-43 \mathrm{U} / \mathrm{L}$ \\
\hline iii. & GGT & $189 \mathrm{U} / \mathrm{L}(\mathrm{H})$ & $6.3-8.2 \mathrm{~g} / \mathrm{dl}$ \\
\hline iv. & Total Protein & $0.50 \mathrm{~g} / \mathrm{dl}(\mathrm{H})$ & $3.5-5 \mathrm{~g} / \mathrm{dl}$ \\
\hline v. & Albumin & $5.10 \mathrm{~g} / \mathrm{dl}(\mathrm{H})$ & \\
\hline C. & Renal Function Tests & & $136-146 \mathrm{meq} / \mathrm{L}$ \\
\hline i. & Serum Sodium & $90.75 \mathrm{meq} / \mathrm{L}(\mathrm{L})$ & $101-109 \mathrm{meq} / \mathrm{L}$ \\
\hline ii. & Serum Chloride & & \\
\hline
\end{tabular}

\section{VITALS}

PR: 94/min, RR: 22/min, BP: 170/110, Temp: $98.4 \%$, SpO2: $98 \%$

Based on the laboratory findings the patient was diagnosed with small cell Neuro
Endocrine Carcinoma of the lung with percutaneous transluminal coronary angioplasty (PTCA) in 2016. Drugs were started based on diagnosis as follows

\begin{tabular}{|c|l|}
\hline S.No. & \multicolumn{1}{|c|}{ DRUG } \\
\hline i. & Inj ceftriaxone 1mg BD \\
\hline ii. & Inj Ondansetron 4 ml TDS \\
\hline iii. & Injection Pantoprazole 40 mg \\
\hline iv. & Tab Atorvastatin 10 mg OD \\
\hline v. & Tab Clopidogrel 75 mg OD \\
\hline vi. & Tab Aspirin75 mg HS \\
\hline vii. & Syp Cody Chlorpheniramine maleate + codeine100 ml TDS \\
\hline viii. & Inj Furosemide 20 mg Stat \\
\hline ix. & Inj Hydrocortisone 50mg TDS \\
\hline x. & Inj Etofyllin +Theophylline100mg BD \\
\hline xi. & Neb Levosalbutamol + Ipratopium QID \\
\hline xii. & Neb Budesonide BD \\
\hline xiii. & Powder Ensure 4Tsf TDS \\
\hline xiv. & Tab Amlodipine 5mg OD \\
\hline xv. & IVF Dextrose sodium chloride solution 8 hourly \\
\hline xvi. & Injection Levosulpiride 75 mg \\
\hline xvii. & Tab Amlodipine 35 mg OD \\
\hline xviii. & Tab Telmisartan 40 mg OD \\
\hline xiv. & Tab Haloperidol 5mg stat \\
\hline
\end{tabular}

After the administration of Injection pantoprazole $40 \mathrm{mg}$ patient developed rashes, itching, vomiting, burning sensation in the whole body, restlessness, fever, and chills immediately within few hours. The injection was stopped immediately and the 
symptoms got better after few hours. So, a culture test was done for checking hypersensitivity to pantoprazole, and the patient was advised to give his pantoprazole allergy history to the doctor in any other hospital before treatment.

\section{DISCUSSION}

\section{Anaphylactic (Type 1) Hypersensitivity Reaction Due To Pantoprazole Administration $^{13,14}$}

1. The drug comes in contact with B-cells containing IgE antibodies on the surface in the host body and this process is called sensitization
2. After Sensitization Plasma cells are released and after releasing these plasma cells also release IgE antibodies.

3. The $\operatorname{IgE}$ antibodies which are released binds firmly to the FC receptors of Basophil-mast cell leading to an influx of water and sodium hence damaging the cell membrane called mast cell degranulation.

4. The granules which are released after degranulation of mast cells release inflammatory mediators like vasoactive peptide (VIP), leukotrienes, neutrophils, eosinophils, and platelet-activating factors, etc leading to hypersensitivity symptoms $^{13,14}$. (figure- 1)

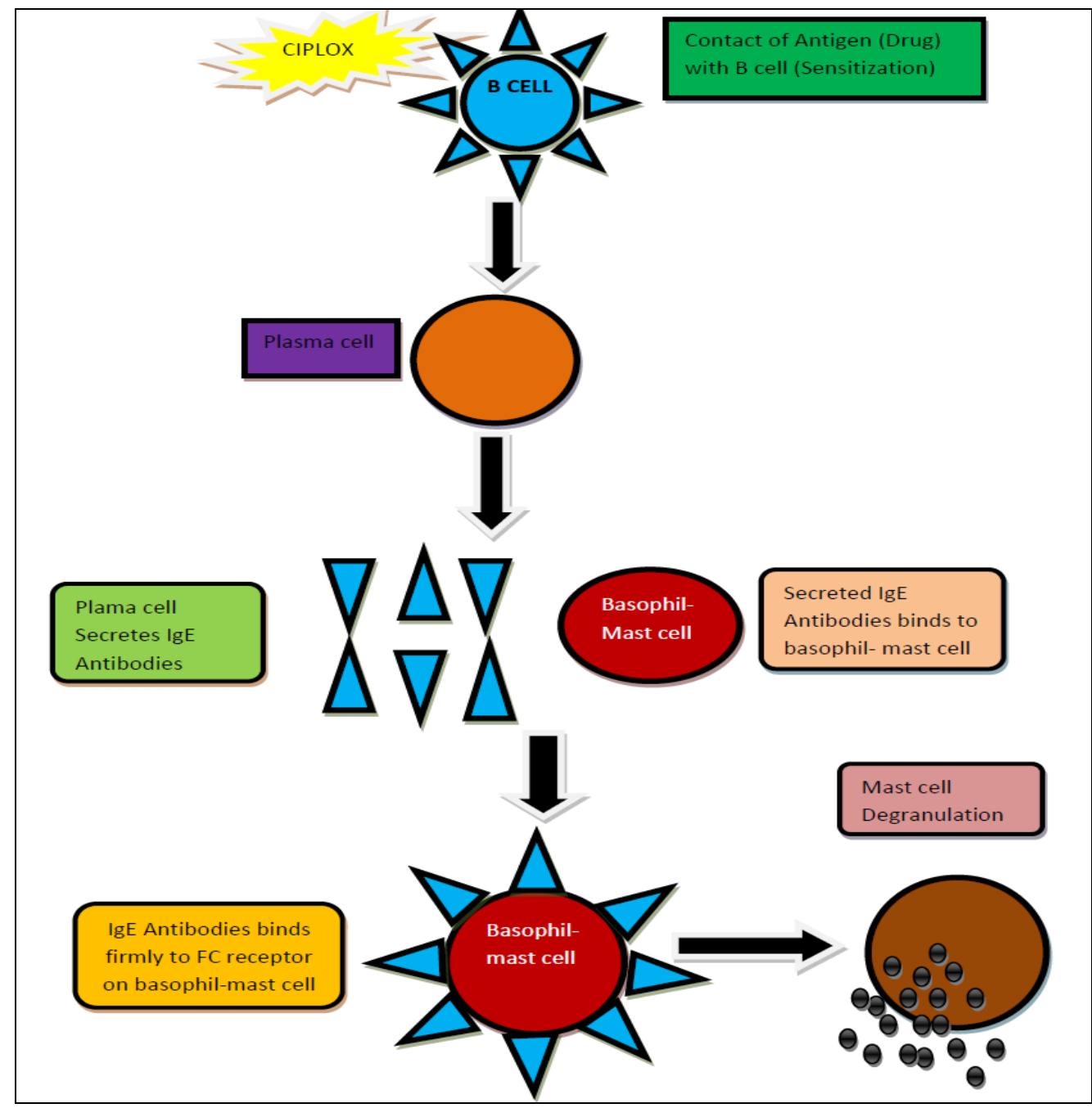

Figure 1: Type-1 Anaphylactic Hypersensitivity Reaction in Patient Due to Pantoprazole Drug

The incidence of hypersensitivity reaction from Proton pump inhibitors and $\mathrm{H} 2$ receptor antagonists is due to the excessive use of the drug as it is given as
OTC medication in India and can have various symptoms ${ }^{\mathbf{1 2}}$. In this case, the patient developed rashes, itching, vomiting, burning sensation in the whole body, restlessness, 
fever, and chills. An anaphylactic reaction can also be life-threatening involving respiratory and cardiovascular problems ${ }^{\mathbf{1 2}}$.

Proton pump inhibitors like pantoprazole decrease gastric $\mathrm{pH}$ which increases bacterial growth in the oral cavity and upper GIT. PPI also inhibits $\mathrm{H}+/ \mathrm{K}+-$ ATPase which is present in the cell membrane of bacteria and fungi. This gives rise to the antimicrobial property of PPI for certain microbes. This change in the microbiome and intestinal bacterial composition along with suppression of gastric $\mathrm{pH}$ is found to be associated with allergic action of the proton pump inhibitors ${ }^{\mathbf{1 5}}$.

\section{CONCLUSION}

It is concluded from the study that increasing use of Proton pump inhibitors is responsible for the anaphylactic hypersensitivity reaction while more detailed information is also required to check the incidence of such ADRs. To check on such ADR's health care professionals should keep an eye on the medication use and its effects and should be cautious while prescribing pantoprazole. Pharmacists should educate the patients regarding possible hypersensitivity reactions from PPIs and how to take these medications to avoid any serious adverse drug reaction.

Acknowledgement: We would like to thank Shri Devendra Das Ji Maharaj and Shri Mahant Indiresh Hospital for supporting us in case monitoring and reporting. We would also like to thank our mentor Dr, Madhulata Rana for the support.

\section{Conflict of Interest: None Source of Funding: None}

\section{REFERENCES}

1. Shin JM, Sachs G. Pharmacology of proton pump inhibitors. Curr Gastroenterol Rep. 2008; 10(6):528-34.

2. Iwakiri K, Kinoshita Y, Habu Y, Oshima T, Manabe N, Fujiwara Y, Nagahara A, Kawamura O, Iwakiri R, Ozawa S, Ashida
K, Ohara S, Kashiwagi H, Adachi K, Higuchi K, Miwa H, Fujimoto K, Kusano M, Hoshihara Y, Kawano T, Haruma K, Hongo M, Sugano K, Watanabe $M$, Shimosegawa T. Evidence-based clinical practice guidelines for gastroesophageal reflux disease 2015. J Gastroenterol. 2016; 51(8):751-67.

3. Richardson P, Hawkey CJ, Stack WA. Proton pump inhibitors Pharmacology and rationale for use in gastrointestinal disorders. Drugs. 1998; 56(3):307-35.

4. Robinson M, Horn J. Clinical pharmacology of proton pump inhibitors: what the practising physician needs to know. Drugs. 2003; 63(24):2739-54.

5. Thomson AB, Sauve MD, Kassam N, Kamitakahara H. Safety of the long-term use of proton pump inhibitors. World $\mathrm{J}$ Gastroenterol. 2010; 16(19):2323-30.

6. Pirson F, Geubel A, Marot L. Late hypersensitivity to omeprazole and other proton pump inhibitors. Acta Clin Belg. 2012; 67(4):301-3.

7. Otani IM, Banerji A. Immediate and delayed hypersensitivity reactions to proton pump inhibitors: evaluation and management. Curr Allergy Asthma Rep. 2016; 16(3):17.

8. Gonzalez P, Soriano V, Lopez P, Niveiro E. Anaphylaxis to proton pump inhibitors. Allergol Immunopathol (Madr). 2002;30(6):342-3.

9. Demirkan K, Bozkurt B, Karakaya G, Kalyoncu AF. Anaphylactic reaction to drugs commonly used for gastrointestinal system diseases: 3 case reports and review of the literature. J Investig Allergol Clin Immunol. 2006;16(3):203-9.

10. Mohan Harsh, Textbook of Pathology, The Health Sciences and Publishers, Edition 7 Page: 58-61.

11. Song WJ, Kim MH, Lee SM, et al. Two cases of H2-receptor antagonist hypersensitivity and cross-reactivity. Allergy Asthma Immunol Res. 2011; 3(2): 128-131.

12. Gupta Pramendra Prasad, et al, Anaphylactic reactions due to pantoprazole: case report of two cases, International Medical Case Reports Journal, 2018:11 125127.

13. Baldo Brian A, Pham Nghia $H$, Mechanisms of Hypersensitivity, Pub med, Drug Allergy. 2013 May 3: 37-90. 
14. Mohan Harsh, Textbook of Pathology, The Health Sciences and Publishers, Edition 7 Page: 58-61.

15. Untersmayr E. Acid suppression therapy and allergic reactions. Allergo J Int. 2015; 24(8):303-311.
How to cite this article: Bahuguna R, Joshi D, Rana M. A case report on allergic reaction to pantoprazole. International Journal of Science \& Healthcare Research. 2021; 6(4): 82-86. DOI: https://doi.org/10.52403/ijshr.20211013 